\title{
Sugammadex and amino acid infusion can contribute to safe anesthetic management of variegate porphyria
}

\author{
Yoshitaka Aoki ${ }^{*}$, Kazuyuki Atsumi, Makiko Kora, Naoko Koh and Junichiro Yokoyama
}

\begin{abstract}
Background: Variegate porphyria (VP) is an inherited type of porphyria characterized by cutaneous manifestations and/or acute neurovisceral attacks. We report successful anesthetic management of VP.

Case presentation: A 66-year-old woman with VP was scheduled to undergo distal pancreatectomy for pancreatic cancer. Medical history was unremarkable except for sudden onset of abdominal pain that occurred every few months, possibly due to VP. There was no abnormality in laboratory data except for a mild increase in creatinine levels. General anesthesia was induced and maintained with total intravenous anesthesia using propofol, remifentanil, and rocuronium. Blood glucose levels were measured every hour and glucose administered to prevent hypoglycemia. Amino acids were also infused to treat hypothermia. Upon completion of distal pancreatectomy, sugammadex was administered to reverse neuromuscular blockade. She was neurologically intact and discharged on postoperative day 15 with no acute attack.
\end{abstract}

Conclusions: Sugammadex and amino acids can be used safely in patients with VP.

Keywords: Porphyria, General anesthesia, Sugammadex, Amino acid infusion

\section{Background}

Variegate porphyria (VP) is an autosomal-dominant disease caused by mutation of the protoporphyrinogen oxidase gene $(P P O X)[1]$. It has a worldwide prevalence of $1 /$ 300,000 individuals. VP is characterized by cutaneous manifestations and/or acute neurovisceral attacks such as vomiting, motor neuropathy, paresis, seizure, agitation delirium, psychosis, electrolyte abnormalities, and renal failure [2]. Avoidance of possible triggers of attacks, such as hypoglycemia and hypothermia, during the perioperative period is very important. Several anesthesia-related agents should also be avoided.

Because of its rarity, much remains to be clarified about the anesthetic management of patients suffering from VP. In this case, we selected two agents used in routine anesthesia: sugammadex (to reverse the actions of the muscle relaxant applied during anesthesia) and an amino acid infusion (to increase body temperature). Sugammadex has been reported in only one VP case [3], and amino acid

\footnotetext{
* Correspondence: ysyaoki27@gmail.com

Department of Anesthesiology, Shizuoka General Hospital, 4-27-1 Kita-Ando, Aoi-Ku, Shizuoka 420-8527, Japan
}

infusion has never been reported in a VP patient. We report successful anesthetic management of a patient with VP undergoing distal pancreatectomy.

\section{Case presentation}

This case report follows CARE (CAse REport) guidelines [4]. We explained the purpose of the study to the patient and obtained written informed consent to publish our findings.

A 66-year-old woman $(63 \mathrm{~kg}$; height, $152 \mathrm{~cm})$ with VP was scheduled to undergo distal pancreatectomy for pancreatic cancer. She had been hospitalized for 3 years at the age of 28 years with abdominal pain, ileus, mental disorder, and quadriplegia. During that time, she was diagnosed with VP based on the results of several types of examination. Although she had undergone a tracheostomy due to quadriplegia during hospitalization, her neurologic symptoms disappeared after hospital discharge. Her only daughter presented with abdominal pain during her twenties, at which time she had been diagnosed with VP. She had suspected that her mother's abdominal pain was also due to VP, although her mother had not been diagnosed with VP definitively. At the present admission, she had a history of 
abdominal pain that occurred every few months, which she had self-treated with sugar intake and body warming. She was also on medications for hypertension and chronic kidney disease. The creatinine level in serum was increased slightly to $2.12 \mathrm{mg} / \mathrm{dL}$, but there were no abnormalities in other laboratory parameters, such as urinary levels of porphobilinogen and delta-aminolevulinic acid.

We selected total intravenous anesthesia (TIVA) with target-controlled infusion (TCI) as a suitable method of anesthesia [5]. In the operating theater, the upper body was covered by a forced air blanket to prevent hypothermia. General anesthesia was induced with TCI of propofol $(3 \mu \mathrm{g} / \mathrm{mL})$ with remifentanil $(0.4 \mu \mathrm{g} / \mathrm{kg} / \mathrm{min})$ followed by rocuronium $(40 \mathrm{mg})$ and tracheal intubation. An indwelling catheter was inserted into the radial artery for regular measurement of levels of glucose and electrolytes in the blood. Anesthesia was maintained with TCI of propofol and remifentanil with monitoring of the bispectral index. Rocuronium was administered intermittently to maintain a train-of-four count of 1 . A total of $0.4 \mathrm{mg}$ of fentanyl was administered intraoperatively, with $50 \mu \mathrm{g} / \mathrm{h}$ of fentanyl administered continuously for postoperative analgesia.

Blood-gas tests were undertaken via the arterial catheter every $60 \mathrm{~min}$, and we checked for electrolyte abnormalities and measured blood glucose levels. All electrolytes were within the normal range intraoperatively. The blood glucose level before as well as $1,2,3$, and $4 \mathrm{~h}$ after starting surgery was 102, 120,121, 106, and $97 \mathrm{mg} / \mathrm{dL}$, respectively. The glucose level decreased $3 \mathrm{~h}$ after starting surgery despite the administration of an extracellular fluid containing $5 \%$ glucose, so we administered glucose (10 g, i.v.). Body temperature decreased from $36.0^{\circ} \mathrm{C}$ preoperatively to $35.5^{\circ}$ $\mathrm{C} 1 \mathrm{~h}$ after starting surgery, so we started the amino acid infusion to increase body temperature [6]. Body temperature 2,3 , and $4 \mathrm{~h}$ after starting the surgery was 35.4, 35.7, and $35.9^{\circ} \mathrm{C}$, respectively. The total volume of the amino acid infusion was $550 \mathrm{~mL}$. Distal pancreatectomy was completed in $224 \mathrm{~min}$. After confirming a train-of four count of 2, sugammadex (140 mg) was administered and the tracheal tube removed, followed by administration of oxygen $(3 \mathrm{~L} / \mathrm{min})$ via a nasal cannula. She was admitted to the high dependency unit. Our patient had no neurologic abnormalities or VP symptoms. She was moved to the general ward on postoperative day 5 and was discharged from the hospital with good progress on postoperative day 15 .

\section{Discussion}

With meticulous care, we achieved safe perioperative management of a patient with VP scheduled for distal pancreatectomy. Perioperative management of porphyria is important to avoid an acute attack, and the anesthesiologist must pay careful attention to address possible triggers during this period. In this case, we focused on the selection of anesthetic drugs and prevention of hypoglycemia and hypothermia.

Porphyrias are metabolic disorders caused by altered activity of enzymes within the heme biosynthetic pathway [7]. Porphyrias can be classified as "acute" (present characteristically with neurovisceral manifestations) or "cutaneous" (present characteristically with skin lesions) [7]. Acute porphyrias include delta-aminolevulinic acid dehydratase porphyria, acute intermittent porphyria, hereditary coproporphyria, and VP. Delta-aminolevulinic acid dehydratase porphyria results in neurovisceral symptoms only. The prevalence of skin lesions increases in the order of acute intermittent porphyria, hereditary coproporphyria, and VP. VP is generated by the PPOX mutation, which can cause various symptoms. The most common symptom of VP is skin lesions and is observed frequently compared with other types of acute porphyria. Skin lesions are seen in $10-50 \%$ of VP patients. Our patient did not have skin lesions.

With regard to acute attacks, symptoms are, in general, non-specific and triggers vary. The common triggers are dehydration, infection, fever, fasting, hypoglycemia, and medications [8]. When our patient suffered abdominal pain, she kept herself warm and consumed sugar to prevent symptom worsening. During general anesthesia, we monitored meticulously for reddish porphyrinuria, electrolyte abnormalities, blood glucose levels, and body temperature, all of which would indicate an acute attack. If we suspected that she was developing an acute attack, we were primed to administer hemin immediately. Fortunately, there were no signs of such an attack, and hemin was not needed. Acute attacks of VP can be life-threatening unless recognized and managed appropriately. Intravenous administration of hemin is recommended if such a development should occur [9].

Selection of the most appropriate drug is highly important. Safe and dangerous drugs are listed on the Internet websites of the American Porphyria Foundation [10], the European Porphyria Network [11], and Sakuratomonokai [12] in Japan (Table 1). Some lists do not agree with others, however, and evidence is limited. In the present case, two drugs not listed for use were administered after explaining the necessity to the patient in advance: sugammadex and amino acid infusion. Sugammadex reverses neuromuscular blockade more rapidly than neostigmine and is associated with fewer adverse events [13]. Amino acid infusion has been reported to increase body temperature and improve clinical outcomes [6]. Accumulation of case reports such as this one could aid safe management of VP.

The choice of the anesthetic method merits discussion. Although the volatile anesthetic desflurane seems to be relatively safe, we selected TIVA using propofol 
Table 1 Recommendations for anesthesia-related drugs in patients with porphyria. This table was created independently by the authors based on data from references [10-12]

\begin{tabular}{|c|c|c|c|c|c|}
\hline Drug category & Safe & Probably safe & Not yet classified & Probably unsafe & Unsafe \\
\hline Anesthetic & $\begin{array}{l}\text { Propofol } \\
\text { Midazolam }\end{array}$ & Desflurane & Sevoflurane & & Thiopental \\
\hline Analgesic & Morphine & $\begin{array}{l}\text { Fentanyl } \\
\text { Remifentanil }\end{array}$ & & Pentazocine & $\begin{array}{l}\text { Diclofenac } \\
\text { Ketamine }\end{array}$ \\
\hline Local anesthetic & Bupivacaine & & & Lidocaine & \\
\hline Muscle relaxant & $\begin{array}{l}\text { Rocuronium } \\
\text { Suxamethonium }\end{array}$ & Vecuronium & & & \\
\hline Vasopressor & Adrenaline & $\begin{array}{l}\text { Phenylephrine } \\
\text { Dopamine }\end{array}$ & Ephedrine & & \\
\hline Vasodilator & & & Diltiazem & & Nifedipine \\
\hline Other & Insulin & Neostigmine & Sugammadex & & $\begin{array}{l}\text { Phenytoin } \\
\text { Phenobarbital }\end{array}$ \\
\hline
\end{tabular}

based on previous reports $[5,14]$. In addition, we did not carry out epidural anesthesia. Anesthesiologists can undertake epidural anesthesia using bupivacaine for postoperative analgesia $[5,14]$. However, if neurologic symptoms occur, it might be difficult to distinguish if they are due to epidural anesthesia or porphyria. Taken together, we considered simple TIVA to be a suitable anesthetic method.

Our case report had a very important limitation: we could not obtain the details of her diagnosis. We contacted the hospital that diagnosed her and her daughter as having VP, but the data were no longer available. Nevertheless, we are confident our patient does have hereditary porphyria based on her family history.

According to CARE guidelines [4], we quote our patient directly: "I was sad when pancreatic cancer was found. Furthermore, I felt sorrow beyond that I was refused surgery at several hospitals because of porphyria. My daughter has the same disease, maybe having the same sad feeling in the future. If my surgical experience is for future patients with porphyria, I will be pleased to report my case."

In conclusion, anesthetic management of VP patients can be undertaken safely if anesthetists pay attention to, and address, the possible triggers of acute attacks. Sugammadex and amino acid infusion may be administered safely to patients with porphyria.

\section{Abbreviations}

PPOX: Protoporphyrinogen oxidase gene; TCl: Target-controlled infusion; TIVA: Total intravenous anesthesia; VP: Variegate porphyria

\section{Acknowledgments}

We thank Dr. Hiroshi Nonogi for carefully proofreading the manuscript.

\section{Authors' contributions}

YA, KA, MK, NK, and JY helped write and edit the manuscript. All authors read and approved the final manuscript.
Ethics approval and consent to participate

Not applicable.

\section{Consent for publication}

Written informed consent to publish this case report was obtained from the patient.

\section{Competing interests}

The authors declare that they have no competing interests.

\section{Publisher's Note}

Springer Nature remains neutral with regard to jurisdictional claims in published maps and institutional affiliations.

Received: 15 May 2018 Accepted: 5 June 2018

Published online: 18 June 2018

\section{References}

1. Brenner DA, Bloomer JR. The enzymatic defect in variegate porphyria: studies with human cultured skin fibroblasts. N Engl J Med. 1980;302:765-9.

2. Harper $\mathrm{P}$, Wahlin $\mathrm{S}$. Treatment options in acute porphyria, porphyria cutanea tarda, and erythropoietic protoporphyria. Curr Treat Options Gastroenterol. 2007:10:444-55.

3. Buijs EJ, Scholten JG, Ros JJ. Successful administration of sugammadex in a patient with acute porphyria: a case report. Eur J Anaesthesiol. 2014;31:439-41.

4. Gagnier JJ, Kienle G, Altman DG, Moher D, Sox H, Kienle G, et al. The CARE guidelines: consensus-based clinical case reporting guideline development. BMJ Case Rep. 2013;2013. https://www.ncbi.nlm.nih.gov/pubmed/24155002.

5. Kuźminski A, Aporowicz M, Brol M, Kuźmiński A, Masternak M. Elective cholecystectomy performed on patient with variegate porphyria-propofolbased total intravenous anesthesia with target-controlled infusion. J Clin Anesth. 2016:35:114-7.

6. Aoki Y, Aoshima Y, Atsumi K, Kaminaka R, Nakau R, Yanagida K, et al. Perioperative amino acid infusion for preventing hypothermia and improving clinical outcomes during surgery under general anesthesia: a systematic review and meta-analysis. Anesth Analg. 2017:125:793-802.

7. Puy H, Gouya L, Deybach JC. Porphyrias. Lancet. 2010;375:924-37.

8. Kumar M, Bose S, Darlong V, Punj J. Congenital erythropoietic porphyria: anesthetic implications. J Anesth. 2009;23:569-71.

9. Marsden JT, Guppy S, Stein P, Cox TM, Badminton M, Gardiner T, et al. Audit of the use of regular haem arginate infusions in patients with acute porphyria to prevent recurrent symptoms. JIMD Rep. 2015;22:57-65.

10. American Porphyria Foundation. org [homepage on the Internet]. Available from: www.porphyriafoundation.com/. Accessed 12 Feb 2018.

11. European Porphyria Network. org [homepage on the Internet]. Available from: www.porphyria-europe.com/. Accessed 12 Feb 2018.

12. Sakuratomonokai. org [homepage on the Internet]. Available from: http:// www.sakuratomonokai.com/. Accessed 12 Feb 2018. 
13. Hristovska AM, Duch P, Allingstrup M, Afshari A. The comparative efficacy and safety of sugammadex and neostigmine in reversing neuromuscular blockade in adults: a Cochrane systematic review with meta-analysis and trial sequential analysis. Anaesthesia. 2018;73:631-43.

14. Minoda Y, Yoshimine K, Higashi M, Nagata E, Ikeda K, Yoshimura N. Anesthetic management of a patient with variegate porphyria. J Anesth. 1997;11:307-8

\section{Submit your manuscript to a SpringerOpen ${ }^{\circ}$} journal and benefit from:

- Convenient online submission

Rigorous peer review

- Open access: articles freely available online

- High visibility within the field

- Retaining the copyright to your article

Submit your next manuscript at $\gg$ springeropen.com 